\title{
The trajectory of the process of democratization in Poland in the light of theory, political praxis and external evaluation: 1989-2019
}

Keywords: Poland, the process of democratization, 1989-2019, the regress of democratization after 2015

\begin{abstract}
In 1989 Poland decided to implement a democratic regime, but its future was uncertain then. Today, after 30 years of the development of the process of democratization, one can say that the road to democracy is winding. The article analyzes the Polish example of the process of democratization between 1989-2019. It refers to existing theories of the process of democratization and the evaluation of democracy. Although Poland passed through the phases of the erosion of a non-democratic regime, transition and democratic consolidation, the situation after 2015 suggests that there are trends that can reverse the process of democratization. It will be argued that the institutional and behavioral aspects of the process of democratization in Poland cannot be perceived as a linear process.
\end{abstract}

* ORCID ID: https://orcid.org/0000-0002-7609-4002, professor at the Institute of Political Sciences, University of Silesia in Katowice. Scientific interests: political systems and political history of the Visegrad Group countries with particular emphasis on Hungary, the process of democratization and its regression, territorial self-government of the Third Republic of Poland; sebastian.kubas@us.edu.pl 


\section{Introduction}

Today, we can observe that democratic backsliding is a worldwide phenomenon. The problem of a democratic recession has also appeared in Central and Eastern European countries. The first symptoms emerged more than a decade ago, with Jacques Rupnik being one of the very first researchers to recognize this trend. In 2007 he argued that there were serious signs of democratic backsliding in Central Europe, which challenged the earlier linear process of liberalist inspired democratization. For example in the Czech Republic, Slovakia, Poland and Hungary this process was connected with the accomplishment of the aims of EuroAtlantic integration. Up to 2004 there was a social and political agreement that liberal democracy was the main aim of the development of the political system, but after that populist and illiberal tendencies began to become more and more popular ${ }^{1}$.

The crisis of democratization developed, and at the end of the third decade from its beginning in Central Europe it embraces both institutional and behavioral aspects. There are two main approaches to the contemporary description of democratic backsliding. Some authors state that democracy is in a temporary crisis which will fade and the situation will return to an earlier liberal form ${ }^{2}$. While the others argue that the trends, we are observing, are more serious and lasting, so liberal democracy is undergoing a deeper transformation ${ }^{3}$.

Regardless of the future of contemporary democratic backsliding, Poland today is an example of the deterioration in the achievements of liberal democratic democratization that started in 1989. Poland was able to peacefully start the process of democratization almost three decades ago, and moreover, for a very long time Poland was recognized as a leader of democratic changes.

The subject of the analysis is to examine what has been happening in Poland during the process of democratization from the 1989 end of com-

1 J. Rupnik, From Democracy Fatigue to Populist Backslide, «Journal of Democracy» 2007, vol. 18, no. 4, pp. 17-19.

2 P.C. Schmitter, Crisis and Transition, but not Decline, [in:] L. Diamond, M.F. Plattner (eds.), Democracy in Decline? Baltimore 2015, pp. 39-57; S. Levitsky, L. Way, The Myth of Democratic Recession, [in:] L. Diamond, M.F. Plattner (eds.), Democracy in Decline? Baltimore 2015, pp. 58-76; L. Diamond, Facing up to the Democratic Recession, [in:] L. Diamond, M.F. Plattner (eds.), Democracy in Decline? Baltimore 2015, pp. 98-113.

3 J. Møller, S.-E. Skaaning, The Third Wave: Inside the Numbers, «Journal of Democracy» 2013, vol. 24, no. 4, pp. 97-119; R.S. Foa, Y. Mounk, The Signs of Deconsolidation, «Journal of Democracy» 2017, vol. 28, no. 1, pp. 5-16. 
munism, through the period of transition, to democratic consolidation. It is interesting to see how the contemporary trend of democratic recession that could be observed in Poland after 2015 relates to the whole process of democratization. The period of analysis ends in 2019 when Law and Justice won again the elections to Sejm in 2019 and continued the process of challenging the process of democratization.

The main thesis of the article is that the institutional and behavioral aspects of democratization in Poland cannot be perceived as a linear process. The thesis is accompanied by the following questions:

1) How can we describe democratization in its liberal dimension?

2) How did democratization manifest itself in Poland after 1989?

3) How can we analyze the contemporary changes after 2015 in Poland?

The methods used during the research process are: analysis and synthesis of the literature, qualitative and quantitative methods, neoinstitutional approach and case-based study ${ }^{4}$.

\section{Democratization process theory and the contemporary stagnation of democratic consolidation}

The process of democratization is to transform a non-democratic regime into a democratic one. The whole process is complicated and consists of many aspects and phases. Briefly, the two most important aspects of consolidated democracy are: procedures and behavior ${ }^{5}$. The procedural approach refers to the introduction of the following constitutional principles into a political system: power separation, transparency of activity of public authorities, popular elections, freedom of association, freedom of speech, access to alternative information, the accountability of officials ${ }^{6}$. From a behavioral point of view democracy is thought to be rooted when the political elites and the wider society obey democratic values. It must be underlined that a substantive democracy must respect the rights of the minority, although the right to govern is given to the majority ${ }^{7}$.

4 M. Bogaards, Case-based Research on Democratization, «Democratization» 2019, vol. 26, no. 1, pp. 61-77; W. Beywl, The Role of Evaluation in Democracy: Can it be Strengthened by Evaluation Standards? A European Perspective, "Journal of Multidisciplinary Evaluation» 2006, no. 6, pp. 10-29; M. Coppedge, D. Kuehn, Introduction: absorbing the four methodological disruptions in democratization research?, «Democratization» 2019, vol. 26, no. 1, pp. 1-20; A. Chodubski, Wstęp do badań politologicznych, Gdańsk 2004.

5 A. Antoszewski, Wspótczesne teorie demokracji, Warszawa 2016, pp. 180-181.

6 R. Dahl, Demokracja i jej krytycy, Warszawa 2012, pp. 316-317.

7 G. Sartori, Teoria demokracji, Warszawa 1998, pp. 170-175. 
The process of democratization is a long and enduring journey that probably never ends ${ }^{8}$. Yet, as time goes by, the process matures and changes. There are a number of concepts concerning the chronological division of the process of democratization ${ }^{9}$, but many of them argue that the three main phases are: the erosion of the non-democratic regime, transition, and the consolidation of democracy. During the erosion of an non-democratic regime the authorities cannot cope with the rising crisis of the social, economic and political systems. Finally the political elites concede (but they can negotiate the form of the regime change) and they are replaced by new forces ${ }^{10}$. The second phase of the process of democratization is the transition which lasts several years. During this stage new political elites work on the implementation of new procedures and structures for state which allows it to act like a democratic regime. It is believed that there are nine institutional elements that are constructed or reshaped during transition: the state structure, national identity, the Constitution, the model of relations between the organs of power, the party system, the electoral system, decentralization, reference to international conditions ${ }^{11}$. Among the many concepts concerning the determining of the end point of the transition, this article will select the one that states that the transition lasts until the basic and formal democratic rules have been implemented. These rules can be formally included in a constitution. Then the third and the longest phase begins, which is democratic consolidation. This stage goes beyond the institutional aspect connected with transition because it refers to the behavioral sphere of democracy and joins democratic values with social attitudes.

8 J. Iwanek, Standardization of Modern Democracy, «Studia Politicae Universitatis Silesiensis» 2015, vol. 13, pp. 13-24.

9 A. Przeworski, Democracy and the Market. Political and Economic Reforms in Eastern Europe and Latin America, Cambridge 1991; S. Huntington, The Third Wave of Democratization, University of Oklahoma Press 1991; L. Whitehead, Democratization. Theory and Experience, Oxford 2002; G. Pridham, The Dynamics of Democratization. A Comparative Approach, London and New York 2000.

10 G. O'Donnell, P.C. Schmitter, Tentative Conclusions about Uncertain Democracies, [in:] G. O'Donnell, P.C. Schmitter, L. Whitehead (eds.), Transition from Authoritarian Rule, Baltimore 1986, p. 8; J.S. Valenzuela, Democratic Consolidation in Post-Transitional Setting: Notion, Process, and Facilitating Conditions. Kellogg Institute Working Paper, https://kellogg.nd.edu/ publications/workingpapers/WPS/150.pdf (25.03.2019); A. Przeworski, Democracy and the Market. Political and Economic Reforms in Eastern Europe and Latin America, Cambridge 1991, pp. 66-79.

11 S. Kubas, Proces demokratyzacji i jego determinanty. Analiza na przykładzie Republiki Cizeskiej $i$ Wegier (1990-2016), Katowice 2018, p. 382. 
Early democratic consolidation can be still very fragile and can be prone to stopping or regressing ${ }^{12}$.

In the literature for a long time democratic consolidation was perceived as a one way road. When a state has become both institutionally and behaviorally liberal democratic, even if it had some failures, it was thought that democratization would continue to strengthen ${ }^{13}$. But today much has changed, and we do not know if the spreading wave of democratic backsliding will come to an end, and the process of democratic consolidation will eventually come home to its liberal democratic nest. So, nowadays it is important to examine the reasons for democratic backsliding, which has halted the process of democratization, and try to analyze the key features of this situation.

Generally the process of democratization is connected with liberal democracy, so the stagnation is a challenge to the liberal values that reside in democracy. Some of the most important ones are: constitutionalism, the rule of law, guarantees of human rights, free elections ${ }^{14}$, the separation of powers, the political neutrality of the civil service, public media independence ${ }^{15}$. Instead of these liberal democratic rules and values democratic backsliding introduces the opposite values that have an illiberal character such as: statism, the primacy of the state and nation sovereignty ${ }^{16}$, an undermining of the universal nature of human rights ${ }^{17}$, the lack of a belief in the importance of constitutionalism ${ }^{18}$, and the subordination of the activities of non-governmental organizations by the authorities ${ }^{19}$.

12 G. Pridham, The Dynamics of Democratization. A Comparative Approach, London and New York 2000, p. 249; A. Ágh, Globalization and Central European Countries' Democratization. The Fourth Wave, [in:] R. Markowski, E. Wnuk-Lipiński (eds.), Transformative Paths in Central and Eastern Europe, Warsaw 2001, p. 99.

13 R.S. Foa, Y. Mounk, The Signs of Deconsolidation, «Journal of Democracy» 2017, vol. 28, no. 1, p. 9.

14 M.F. Plattner, Illiberal Democracy and the Struggle on the Right, «Journal of Democracy» 2019, vol. 30 , no. 1 , p. 8.

15 J. Rupnik, Explaining Eastern Europe: the Crisis of Liberalism, «Journal of Democracy» 2018, vol. 29, no. 3, p. 25.

16 A. Cooley, Countering Democratic Norms, «Journal of Democracy» 2015, vol. 26, p. 50.

17 S. Berman, The Pipe Dream of Undemocratic Liberalism, "Journal of Democracy» 2017, vol. 28, no. 3, pp. 29-38; F. Zakaria, The Rise of Illiberal Democracy, «Foreign Affairs» 1997, vol. 76, no. 6 , pp. 22-43.

18 R.S. Foa, Y. Mounk, The Democratic disconnect, «Journal of Democracy» 2016, vol. 27, no. 3, pp. $5-17$.

19 I. Krastev, The Strange Death of Liberal Consensus, «Journal of Democracy» 2007, vol. 18, no. 4, pp. 56-63. 
The contemporary debate focuses on the explanation of the examples of democratic backsliding in the light of existing theories. These theories are mostly normative ones because they enumerate factors needed to state if a given example is democratic or not.

One such theory was suggested by Jørgen Møller and Svend-Erik Skaaning, who examined the countries of the world on the basis of the following structural factors: socio-economic, ethnicity, bureaucracy and oil wealth. Moreover, they constructed a typology of political regimes by using the Freedom in the World Survey to examine the extent of democracy functioning in a given country. They were interested in elections (quality, competitiveness), political liberties, and the rule of law, so they employed the Freedom in the World indicators: electoral process, political pluralism and participation, freedom of expression and belief, associational and organizational rights, the rule of law. They referred to scores given in the above-mentioned areas and then transferred them onto a simplified scale ${ }^{20}$, and from this they were able to suggest four types of democracy: minimalist, electoral, polyarchy, liberal. To qualify a country for a minimalist democracy, it should get at least from 7 to 11 out of 12 points from the indicator of electoral process. To be an electoral democracy a country should receive 11 or 12 points from the mentioned above indicator. Then a country can be granted a name of polyarchy when it is a minimalist, electoral democracy and gets at least 11 out of 12 points from the indicator associational and organizational rights and 14 out of 16 points from the indicator freedom of expression and belief. Liberal democracy must be minimalist, electoral democracy and polyarchy. Then it should get 14 out of 16 points from the indicator the rule of law.

- Minimalist democracy merely requires political rivalry amongst the elites to reach the highest possible position after free and regular parliamentary elections. The outcome of the elections is uncertain.

- Electoral democracy needs the establishing of more stable and procedural rules of political competition and cooperation than the minimalist one, there are free, inclusive and competitive elections, all citizens have the possibility to participate in the elections.

- Polyarchy goes beyond the earlier requirements of minimal and electoral democracy and guarantees respect for rights and the freedom of speech and association.

20 J. Møller, S.-E. Skaaning, Regime Types and Democratic Sequencing, «Journal of Democracy» 2013, vol. 24, pp. 142-155. 
- Liberal democracy merges free political competition, freedom of speech and association, the rule of law, equality under the law ${ }^{21}$.

\section{The Polish experiences of the process of democratization}

\section{9-1997: transition}

The erosion of the non-democratic Polish regime can be classified as an example of a pact or negotiated transition ${ }^{22}$. At the end of 1980's, the dominant political organization, the socialist Polish United Worker's Party (pol. Polska Zjednoczona Partia Robotnicza, PZPR), decided to talk to the opposition, which was mostly represented by Solidarity (pol. Solidarność). The talks were both formal and informal and focused on searching for solution of deepening crisis in Poland. The roundtable negotiations lasted from February $6^{\text {th }}$ to April $5^{\text {th }} 1989$ and ended with an agreement to run elections for the Sejm (lower chamber of parliament) and the Senate (the upper chamber was introduced for the first time after II World War). The socialist elite was able to guarantee some privileges for itself like the fact that only pro-regime candidates could compete for $65 \%$ of the seats in the Sejm, while only $35 \%$ of the seats were allowed to be freely contested. In contrast, all the seats in the Senate were allowed to be freely contested. Then on April $7^{\text {th }} 1989$ the Sejm passed a bill allowing free association, which enabled political parties, other than pro-regime parties to establish their structures ${ }^{23}$. The roundtable negotiations underlined the will of the socialist elite and the opposition to introduce a democratic regime to Poland.

The semi-free elections to the Sejm and free ones to the Senate were took place on June $6^{\text {th }} 1989$. The $35 \%$ of seats of the Sejm that were freely contested were taken by the opposition (mostly Solidarity), while the $65 \%$ of seats in the unfree elections were divided between the PZPR and other pro-regime parties like: Democratic Union (pol. Stronnictwo

21 J. Møller, S.-E. Skaaning, Democracy and Democratization in Comparative Perspective. Conceptions, Conjunctures, Causes, and Consequences, London-New York 2013, pp. 43-44; J. Møller, M. Seeberg, S.-E. Skaaning, Asymmetrical Constraints on Democratic Regime Types: A Comparative Study, https://pdfs.semanticscholar.org/178e/23a4483f909582c556886ddef4670c1e691a.pdf (4.12.2019).

22 J.J. Linz, A. Stepan, Problems of Democratic Transition and Consolidation: Southern Europe, South America, and Post-Communist Europe, Baltimore-London 1996, pp. 264-269.

23 Ustawa z dnia 7 kwietnia 1989 r. Prawo o stowarzyszeniach, Dz.U. z 1989 r. Nr 20, poz. 104. 
Demokratyczne, SD) and United People's Party (pol. Zjednoczone Stronnictwo Ludowe, ZSL). All the freely contested elections to the Senate were won by the opposition. In August 1989 a Solidarity member, Tadeusz Mazowiecki was appointed prime minister by the Sejm and he constructed the first non-communist government that consisted of Solidarity, the SD and the ZSL. At the end of December 1989 the Sejm passed amendments to the 1952 Constitution ${ }^{24}$.

After the elections the new government had to change many aspect of life in Poland, including changes leading to the implementation of the first democratic rules. The PZPR reorganized its structures as well as the ZSL, and the SD, while the opposition movement Solidarity started to fragment. In June 1990 the Sejm passed an Act on free political parties ${ }^{25}$.

After this initial phase of changes the political situation in Poland led to the removal of the old reminders of socialism. At the end of 1990, Lech Wałęsa, a Solidarity leader, was elected to be the President of Poland. In 1991 he dissolved the semi-free parliament and the first free elections to the Polish parliament were held. The fragmentation of the Polish party system was so great that 29 parties were elected to the Sejm and 22 parties were elected to the Senate ${ }^{26}$.

The first free elections opened the transition phase, which can be analyzed with reference to nine elements. The first one, state structure, was not changed. Poland remained within the same borders as it was before 1989. The second element, national character was not greatly reshaped as Poland was and is a homogenous nation with very few minorities. National character means that people reflect collective attitudes, belief due to the cultural and historical background ${ }^{27}$. In general Polish social culture, in the beginning of transition based on catholic values, attachment to family, rather conservative perception of life. After 1989 these values changed a little bit due to globalization process and the process of democratization, yet still describe common and dominant features of Poles.

The third element, the constitution, caused some problems and took some years to finally resolve. The main aim of the newly elected 1991 Parliament was to pass a constitution. Just after the elections three parties

24 Ustawa z dnia 29 grudnia 1989 r. o zmianie Konstytucji Polskiej Rzeczypospolitej Ludowej, Dz.U. z 1989 r. Nr 75, poz. 444.

25 Ustawa z dnia 28 lipca 1990 r. o partiach politycznych, Dz.U. z 1990 r. Nr 54, poz. 312.

26 A. Albert, Najnowsza historia Polski. 1914-1993. Tom 2, London 1994, pp. 906-911.

27 F. Neiburg, International Encyclopedia of the Social \& Behavioral Sciences, https://www.sciencedirect.com/science/article/pii/B0080430767009207?via\%3Dihub\#! (24.06.2020). 
proposed their draft constitutions: the Polish People's Party (pol. Polskie Stronnictwo Ludowe, PSL), the Christian National Union (pol. Zjednoczenie Chrześcijańsko-Narodowe, $\mathrm{ZChN}$ ) and the Democratic Union (pol. Unia Demokratyczna, UD) with the Liberal-Democratic Congress (pol. Kongres Liberalno-Demokratyczny, KLD). Parliament appointed a Constitutional Commission and in 1992 passed an Act on the rules for preparing the constitution. In October 1992 Parliament passed the so called Small Constitution, which was a holding measure until a new full constitution could be passed ${ }^{28}$. The Small Constitution differed from its predecessor by the removal of all previous normative references to socialism and introduced a democratic regime with the division and separation of powers, democratic state of law and the rights and freedom of citizens. Yet due to the chaos and ineffective decision making of the parliament, the government's President L. Wałęsa dissolved the Sejm. The new Sejm and Senate were elected in October 1993. This Parliament drafted the new Constitution and finally in April 1997 this Act was passed and then accepted by Poles in a national referendum in May 1997. The 1997 Constitution reflects the spirit of consensus reached by all the parliamentary parties; both the ruling ones: the Democratic Left Alliance (pol. Sojusz Lewicy Demokratycznej, SLD) and the PSL, and the opposition like the $\mathrm{UD}^{29}$. It must be stated that the composition of the 1993-1997 Sejm was not representative as many right-wing groupings did not reach the 5 percent threshold in the 1993 elections ${ }^{30}$. So mostly the left and the center worked on constitution and passed this Act.

The fourth element of transition refers to the model of relations between the branches of state authorities. According to Rafał Glajcar the model of the relations was close to semi-presidentialism in the period between 1989-199731 because Lech Wałęsa tried to strengthen his domination. Yet in the second half of nineties XXth century a symmetrical bicameralism emerged, with the Sejm being the dominant house and the Senate as a second chamber. Both chambers are elected every four years. Executive power belongs to the government and the popularly

28 Ustawa Konstytucyjna z dnia 17 października 1992 r. o wzajemnych stosunkach między władzą ustawodawczą i wykonawczą Rzeczypospolitej Polskiej oraz o samorządzie terytorialnym, Dz.U. z 1992 r. Nr 84, poz. 426.

29 W. Skrzydło, Ustrój polityczny RP w świetle Konstytucji z 1997 r., Warszawa 2014, pp. 42-54.

30 R. Glajcar, System partyjny III Rzeczypospolitej, [in:] M. Barański, A. Czyż, R. Glajcar, S. Kubas, M. Migalski, R. Rajczyk, M. Tyrała, Wspótczesne partie i systemy partyjne państw Grupy Wyszehradzkiej w procesie demokratyzacji, Katowice 2018, p. 63.

31 R. Glajcar, Demokratyczny rezim polityczny. Relacje między legislatywa i egzekutywa w III Rzeczypospolitej, Katowice 2015, pp. 300-371. 
chosen president, who is elected every five years, but he/she can only be re-elected once. There also is the judicial system.

The new democracy in Poland freed up the system of political parties (the fifth element of transition). Rafał Glajcar calls the situation that emerged in Poland at the beginning of the 1990's a system of small parties. In the 1991 election 111 political organizations stood for parliamentary seats. The outcome necessitated the forming of minority and multi-coalitional governments ${ }^{32}$.

The sixth element of transition, the rules of the electoral system were changed several times. The politicians simultaneously wanted the rules to benefit their interests, as well as to make it possible for the whole society to elect their representatives. The 1989 elections were run on the basis of the April $7^{\text {th }} 1989$ amendments to 1952 Constitution. The 1991 elections to the Sejm were run using proportional representation. To transfer votes the Hare-Niemayer method was used in constituencies, and the Sainte-Laguë method was used for the whole country list system. In 1993 elections the Sainte-Laguë method was changed to the d'Hondt method 33 .

The seventh element, decentralization meant that the Polish territorial system of governance was changed. In 1990 self-government was introduced at the level of the local community. This decentralization reform was completed in 1998 when the Parliament introduced the larger local administrative units of the powiats and the voivodeships ${ }^{34}$.

The eighth element, the external surroundings of transition was connected with the decision of Polish government to join the European Economic Community and NATO. In 1991 Poland became a member of the Council of Europe.

In summary, the Polish transition fulfilled its principled aims in these eight years, with Poland transitioning from a non-democratic regime to a democracy. All the main institutional tasks were accomplished with the passing of the democratic 1997 Constitution, which was accepted by Poles in a national referendum. If we refer these changes to the typology suggested by J. Møller and S.-E. Skaaning, Poland made great steps

32 R. Glajcar, System partyjny III Rzeczypospolitej, [in:] M. Barański, A. Czyż, R. Glajcar, S. Kubas, M. Migalski, R. Rajczyk, M. Tyrała, Wspótczesne partie i systemy partyjne państw Grupy Wyszehradzkiej w procesie demokratyzacji, Katowice 2018, pp. 59-62.

33 W. Wojtasik, Funkcje wyborów w III Rzeczypospolitej. Teoria i praktyka, Katowice 2012, pp. $147-155$.

34 M. Barański, S. Kubas, Samorząd terytorialny w Rzeczypospolitej Polskiej, [in:] M. Barański (ed.), Samorząd terytorialny w Europie Środkowej $i$ Wschodniej, Toruń-Katowice 2009, pp. 163-168. 
forward by moving from a minimalist democracy in 1989, to an electoral one in 1991, and was preparing to develop into a polyarchy.

\section{7-2005: early steps in the consolidation of democracy}

After passing the Constitution in Autumn 1997 Poles voted in their third free parliamentary election, which handed power to the Right. Solidarity Electoral Action (pol. Akcja Wyborcza Solidarność, AWS) which was a coalitional organization of post-Solidarity movements won. It then formed a coalitional government with the Union of Liberty (pol. Unia Wolności). This government, under the leadership of Jerzy Buzek, implemented important reforms in four areas: administration, education, the health system and the pensions system. However, in 2000 the UW left the coalition and the AWS was effected by internal divisions. In contrast, the Polish Left became more united and they benefited from this situation. The SLD won the 2001 election and formed a coalition with the PSL and the Labour Union (pol. Unia Pracy).

The results of 2001 election were interesting. Firstly, after a four year break the SLD was able to regain power. Secondly, two new parties emerged from the disintegration of the AWS and the UW and these won seats in Parliament: Civic Platform (pol. Platforma Obywatelska, PO) and Law and Justice (pol. Prawo i Sprawiedliwość, PiS). PO and PiS would go on to dominate the Polish party system in the years to come. Thirdly, antisystem parties won seats: Self-defence of the Republic of Poland (pol. Samoobrona) and the League of Polish Families (pol. Liga Polskich Rodzin, LPR), which meant that some Polish voters were not satisfied with the process of democratization process and other changes in the country.

The main achievement of the SLD-UP-PSL government was the accession of Poland to the European Union in May, 2004. But at the same time the SLD was losing popular support, as the party was struck by personal conflicts and huge corruption scandals like the Rywin Affair and the Starachowice affair ${ }^{35}$. Finally, the SLD, first lost in the elections to European Union Parliament in 2004, and the following national elections to the Sejm and the Senate in 2005.

The external evaluation of democratization by Freedom House, which was used by J. Møller and S.-E. Skaaning in their typology and

35 W. Wojtasik, Lewica i prawica w Polsce. Aspekty ekonomiczno-społeczne, Sosnowiec 2011, pp. 76-77. 
classification, gave Poland positive scorces in the early years of democratic consolidation. From 1999 to 2004 Poland was awarded a score of 1.5 out of seven by the Freedom Rating (Freedom in the World), with a score of one being the best, and a score of seven being the worst. The Freedom Rating included: civil liberties (two points) and political rights (one point) ${ }^{36}$. Aggregated data of J. Møller and S.-E. Skaaning's typology (electoral process, associational and organizational rights, freedom of expression and the rule of law) classifies Poland among polyarchies.

\section{5-2007: a short deterioration in the consolidation of democracy}

The 2005 parliamentary elections were won by PiS, but they did not get an absolute majority in the Sejm, so Kazimierz Marcinkiewicz formed a minority government. The leader of PiS, Jarosław Kaczyński, did not want to become the prime minister. Earlier in the same year his twin brother Lech was elected as President of Poland. The two political and electoral campaigns of 2005 were dominated by the rivalry between $\mathrm{PiS}$ and PO, and both were won by PiS. This could indicate that voters agreed with PiS, that the Polish liberal democratic changes from 1989 were not appropriate and gave too much space for freedom and Western values that excluded the traditional and conservative aspects of Polish culture $^{37}$. The PiS government initiated reforms of the Polish intelligence service, and to reduce the influence of officials with connections to the old regime they introduced a policy of lustration. The government was anti-Russian and pro-American. In 2006 Jarosław Kaczyński replaced Kazimierz Marcinkiewicz, with him heading a government consisting of PiS, the LPR and Samoobrona. However, in 2007 the Vice-Premier and the leader of Samoobrona was accused of corruption and was dismissed, which resulted in the government collapsing and new elections being held.

After two years of first PiS government Poland was still placed among the polyarchies in 2008 by J. Møller and S.-E. Skaaning ${ }^{38}$.

Jacques Rupnik has suggested that PiS won the 2005 elections because Poles were revealing their anti-liberal attitudes and even-antidemocratic

36 Freedom House. Poland. https://freedomhouse.org/report/freedom-world/2004/poland (4.12.2019).

37 T. Bojarowicz, Partie i ugrupowania prawicowe w Polsce po 1989 roku, Toruń 2013, p. 281.

38 J. Møller, S.-E. Skaaning, Beyond the Radial Delusion: Conceptualizing and Measuring Democracy and Non-democracy, «International Political Science Review» 2010, vol. 31, no. 3, p. 277. 
views. Some Poles did not trust in the democratic institutions and the political elites that were responsible for democratization ${ }^{39}$.

\section{7-2015: an improvement in the quality of the consolidation of democracy}

After a two year deterioration of liberal democratization in Poland the outcome of 2007 election suggested that Poland could get back on track to becoming a liberal democracy. PO won the elections, and PiS came second, while their former coalition partners, the LPR and Samoobrona, lost all their seats. The PSL and Left and Democrats also won seats the Sejm. PO and the PSL formed a coalitional government, and Donald Tusk became the prime minister. The results of the 2011 election also led to a PO and PSL collation government.

The government made some important reforms that were directed towards modernizing Poland: raising the retirement age to 67, lowering the obligatory age children began school to six, a law reforming Higher Education, increasing the sum of money devoted to non-governmental organizations, reform of the health system, expanding the network of roads and highways, maintaining the progress of economic growth. More of abovementioned reforms could be interpreted as global conditions for the development of procedural and behavioral aspects of the process of democratization.

At the same time the PO-PSL collation government were confronted with the challenge of closing the open pension funds due to a lack of money in the budget, and corruption scandals that were connected with $\mathrm{PO}$ politicians.

During the PO-PSL government Poland met the requirements of a transparent and fair electoral process, developed the area of human and civil rights and liberties in accordance with the standards of consolidated democracies. However, there were lengthy court proceedings that effected in a bad way the process of democracy consolidation ${ }^{40}$.

During the PO-PSL government Poland was regarded as polyarchy in J. Møller and S.-E. Skaaning's typology achieving in the two last years (2014 and 2015) 12 points from the indicator electoral process and asso-

39 J. Rupnik, From Democracy Fatigue to Populist Backslash, «Journal of Democracy» 2013, vol. 24, pp. $17-25$.

40 R. Glajcar, S. Kubas, Democratization in Poland in the Light of Quantitative Analysis Based on Selected Indices of the Years 2006-2016, [in:] A. Turska-Kawa, M. Hacek, Democratization Processes in Poland and Slovenia. Comparative Study, Maribor 2016, pp. 23-35. 
ciational and organizational rights, 13 from the rule of law and 16 from freedom of expression.

\section{5-2019: the regression of democratization}

The eighth elections to the Sejm and the Senate were held in Poland on October $25^{\text {th }}$ 2015. PiS received 235 seats, which was more than half, and this enabled them to form a majority government, with Beata Szydło as the Prime Minister. The other parties in the Sejm were: PO, KWW Kukuz'15, Nowoczesna and the PSL. The leftwing SLD did not win any seats ${ }^{41}$. The shift in power was a clear sign that Poles had lost confidence in $\mathrm{PO}$ and liberal democratic change. This was also partly the result of the confrontational and contradictory approach taken by PiS. During the electoral campaign PiS offered an antagonistic model of governance that divided Poles into good ones and the bad ones. The former, were those who accepted catholic, traditional, conservative views, while the latter were those who shared more liberal opinions. As a result PiS wanted to reshape the progress of Polish achievements achieved during the 25 years of the process of democratization.

After the elections, PiS began to realize their electoral program, which consisted of three main elements: education, the pension system, and the social welfare system. Generally, the program contradicted many aspects of the previous reforms and manifested dissatisfaction with changes introduced by PO. The educational system was changed back to how it was before the PO inspired reforms. The new reform removed the newly introduced third level of school, reverting back to the situation before 1999 with two levels: primary and secondary school. Moreover, the PO reform of compulsory education starting at the age of six was cancelled, with it being returned to the age of seven. The pension system reform lowered the age of retirement to 65 for men and 60 for women. In 2016 PiS launched the, "Family 500" program which was intended to increase the number of children in Poland by offering 500 zlotych every month to families with children ${ }^{42}$.

The abovementioned three social-economic reforms introduced by $\mathrm{PiS}$ could be interpreted as a reverse step of what pro-liberal PO did. It seems that liberal economic politics of 2007-2015 was replaced by the

41 Państwowa Komisja Wyborcza. https://parlament2015.pkw.gov.pl/ (3.12.2019).

42 R. Miernik, Reformy Prawa i Sprawiedliwości - nowy kierunek rozwoju państwa czy skuteczna strategia wyborcza, «Studia Politicae Universitatis Silesiensis» 2018, vol. 20, pp. 99-116. 
social and conservative one. So, in the light of the process of democratization PiS changed the social-economic conditions and surroundings of Polish democracy.

Then PiS started to increase its power over the independent public media and the judicial system. In December 2015 the Sejm passed amendments to the Broadcasting Act ${ }^{43}$ that redefined the existing situation. The members of the public media councils and management were now to be appointed and dismissed by the Minister for the Media, instead of the National Broadcasting Council. All previous members of the councils and management staff were dismissed. The changes made the national and local public media more obedient to the government, with Polish public television and radio becoming a propaganda tool of the ruling PiS government. It presenting false information about the opposition to discredit them, while at the same time assisted PiS in its bid to be reelected ${ }^{44}$.

In October 2015 the Sejm elected 5 judges of the Constitutional Tribunal, but in December the new Sejm dominated by PiS elected 5 other judges in their place. At the beginning of December the President Andrzej Duda swore in the judges elected in December ${ }^{45}$. The Constitutional Tribunal stated that the elections of the three October judges were valid, but two of them were not. So only two of the November judges could take their office, while three of the October could do the same. The Prime Minister Beata Szydło refused to publish the Constitutional Tribunal statement and President A. Duda refused to recognize the statement ${ }^{46}$. In December 2015 Parliament changed the law and reorganized the Constitutional Tribunal ${ }^{47}$. In July 2016 Parliament passed a new Act for the Constitutional Tribunal ${ }^{48}$. In August 2016 the Constitutional Tribunal stated that the Act was partly unconstitu-

43 Ustawa z dnia 30 grudnia 2015 r. o zmianie ustawy o radiofonii i telewizji, Dz.U. z 2016 r. poz. 25.

44 M. Mieżejewski, Polityczne konsekwencje nowelizacji ustaw medialnych $w$ Polsce $w$ latach 2015-2016, «Politeja» 2018, vol. 15, no. 55, pp. 287-307.

45 M. Szuleka, M. Wolny, M. Szwed, Kryzys konstytucyjny $w$ Polsce. 2015-2016, pp. 7-8, http:// www.hfhr.pl/wp-content/uploads/2016/09/HFPC-Kryzys-konstytucyjny-w-Polsce-2015-2016. pdf $(22.06 .2020)$.

46 M. Gryń, Historia o tym, jak PiS podporzadkowat sobie Trybunat Konstytucyjny, „Polityka” from November 30, 2016, https://www.polityka.pl/tygodnikpolityka/kraj/1685206,1, historia-otym-jak-pis-podporzadkowal-sobie-trybunal-konstytucyjny.read (22.06.2020).

47 Ustawa z dnia 22 grudnia 2015 r. o zmianie ustawy o Trybunale Konstytucyjnym, Dz.U. z 2015 r., poz. 2217.

48 Ustawa z dnia 22 lipca 2016 r. o Trybunale Konstytucyjnym, Dz.U. z 2016 r. poz. 1157. 
tional ${ }^{49}$. During this crisis the European Commission made several recommendation that asked the Polish government to respect the rule of law and the Constitution ${ }^{50}$. In 2019 Parliament appointed new judges, who were loyal to PiS, two of these judges have very controversial backgrounds: Krystyna Pawłowicz and Stanisław Piotrowicz ${ }^{51}$.

In July 2017 the Sejm passed a new Act for the Supreme Court, which enabled the executive branch to dismiss all its judges. However, this Act was vetoed by President Andrzej Duda. Then in September 2017 he presented his proposed 'reform'. This proposal introduced, 'extraordinary complaint', that made it possible to undermine all the judgements of the judiciary. He also proposed that the age of retirement of Supreme Court judges should be reduced from 70 to 65, and to make retirement at this age obligatory. This proposal was passed as an Act in December 201752. This would result in the President of the Supreme Court being dismissed as she was 66, but the Supreme Court passed a resolution stating that President Małgorzata Gersdorf should stay in office to the end of her term in office (2020). On December 20 $0^{\text {th }}$ 2017, the European Commission passed a resolution to The European Union Council to use the Article 7 of the Treaty of European Union that enables them to suspend some of the rights of a member state, because of a violation of the rule of law ${ }^{53}$. In December 2019 the Sejm passed a number of amendments to the laws that regulate the judicial system, that limited the independence of the Polish courts ${ }^{54}$.

The conflict between the Government and the Constitutional Tribunal and the judicial system caused the deterioration of the latter's position. The aim of the ruling party, PiS, was to reshape the existing Montesquieuan tripartite division of power and to gather as much political influence as possible. The existing rules for the tripartite division of power like the socio-functional organization of power and the rule of

49 M. Szuleka, M. Wolny, M. Szwed, Kryzys konstytucyjny w Polsce. 2015-2016, p. 37, http:// www.hfhr.pl/wp-content/uploads/2016/09/HFPC-Kryzys-konstytucyjny-w-Polsce-2015-2016. pdf $(22.06 .2020)$.

50 Ibidem, pp. 38-41.

51 P. Kośmiński, Pawłowicz i Piotrowicz ida do TK. Ich wybór będzie bezprawny, „wyborcz.pl” from 21 November, 2019, https://wyborcza.pl/7,75398,25433246,pawlowicz-i-piotrowicz-ida-dotk-bodnar-ich-wybor-bedzie-bezprawn.html (22.06.2020).

52 Ustawa z dnia 8 grudnia 2017 r. o Sądzie Najwyższym, Dz.U. z 2018 r., poz. 5.

53 European Commission. Rule of Law: European Commission acts to defend judicial independence in Poland, https://ec.europa.eu/commission/presscorner/detail/en/IP_17_5367 (22.06.2020).

54 Ustawa z dnia 20 grudnia 2019 r. o zmianie ustawy - Prawo o ustroju sądów powszechnych, ustawy o Sądzie Najwyższym oraz niektórych innych ustaw, Dz.U. z 2020 r., poz. 190. 
checks and balances, were strongly challenged by PiS. This party presents an anti-liberal approach to public life, so the liberal perspective on the political system in Poland is undermined.

During the years 2015-2019 the Sejm passed a number of amendments to the Electoral Code that created a new Chamber in the Supreme Court that is responsible for the validation of election in Poland. Now the Electoral Commissioner can create constituencies. The amendments divided the constituency commission into two bodies, and changed the requirements for electoral officials ${ }^{55}$.

On a wave of criticism of PiS and its politics in 2015, Poles created a movement called Committee of Democracy Defense (pol. Komitet Obrony Demokracji, KOD). KOD monitors and evaluates public life, organizes public demonstrations against violations of the democratic rules. At the same time Polish political parties like PO, the SLD and the PSL tried to oppose the deterioration of democracy in Poland, yet the actions of opposition to fight for liberal democracy were contested by PiS.

On October $13^{\text {th }}$ 2019, PiS won a second election victory in the Sejm (235 seats out of 460), but they did not get a majority of seats in the Senate. This means that PO, Nowoczesna, the PSL and the SLD and independent senators can form a coalition against PiS, that can block some of the legislative proposals of the Government.

During the period of 2015-2019, when PiS was governing Poland, the external evaluators of the trajectory of the process of democratization greatly reduced their scores. According to Freedom in the World after four years of PiS government in 2018 Poland received 11 points from the indicator electoral process, 10 from the indicator associational and organizational rights, 14 from the indicator freedom expression and 11 from the rule of law ${ }^{56}$. The abovementioned scores imply that Poland was not regarded as polyarchy and was reduced to electoral democracy in J. Møller and S.-E. Skaaning's typology ${ }^{57}$.

55 Obwieszczenie Marszałka Sejmu Rzeczypospolitej Polskiej z dnia 22 lutego 2019 r. w sprawie ogłoszenia jednolitego tekstu ustawy - Kodeks wyborczy, Dz.U. 2019 poz. 684; Ustawa z dnia 5 stycznia 2011 roku. Kodeks wyborczy, Dz.U. z 2011 r. Nr 21, poz. 112.

56 Freedom House, https://freedomhouse.org/ (17.06.2020).

57 J. Møller, S.-E. Skaaning, Regime Types and Democratic Sequencing, «Journal of Democracy» 2013, no. 1, vol. 24, pp. 142-155. 


\section{Conclusion}

The Polish process of democratization has been a long and winding road. Although it began 30 years ago, and the direction of travel was clearly formulated then as liberal democratic regime, it has encountered obstacles, and today it faces challenges that it has not met before. Thus, the article has demonstrated the thesis that the institutional and behavioral aspects of the process of democratization in Poland cannot be perceived as a linear process.

Answering the first question posed in the introduction concerning if the process of democratization can be analyzed by its division into several phases. There seems to be three main phases: the erosion of non-democratic regime, transition, and democratic consolidation. The first one closes the pre-democratic situation, the second one introduces important procedural rules on how democracy should function, and the third phrase, which is the longest in duration, because it refers to the social adoption of democratic values as well as the strengthening of procedures.

The second question referred to the trajectory of the process of democratization in Poland after 1989. The liberal democratic concept of the regime, that was implemented in Poland in 1989 during the transition, and after that developed into the democratic consolidation, was the priority for the political elites and the wider society for a long time. Poland was perceived as the leader of the process of democratization among Central and Eastern European countries, as well as being favorably classified in the typologies of democratic countries and the external evaluation of indices of Freedom House. The first symptoms of the regression of the process of democratization appeared after 2004 and the accession to EU. After that the common agreement on a linear liberal democratic way of development was challenged by parties that won parliamentary elections in 2005, and who formed a coalitional government in 2006 (PiS, Samoobrona, the LPR). They offered populist and illiberal solutions to public policy issues. Then between 2007-2015 the process of democratization got back on liberal track while PO and the PSL were in government.

During the early period of democratic consolidation, according to J. Møller and S.-E. Skaaning's typology, Poland was classified as a polyarchy. An external evaluation of the process of democratization in Poland by Freedom Rating granted this country the score of 1.5 (1999-2004) and one (2005-2016), while Democracy Score oscillated around 2.2 (2005 to 2015). 
The last question was connected with the contemporary changes after 2015 in Poland. After 2015 the liberal democratic process was challenged by the politics of PiS. The general rule of the tripartite division of power was weakened by the Executive's 'reforms' of the judiciary. Other symptoms of the main political activity of $\mathrm{PiS}$ are: the control over public media, the limiting of the freedom of non-governmental organization, an aggressive attitude towards the opposition, and the undermining of the aspects of human rights concerned with freedom and toleration. After 2015 Poland can be classified as a polyarchy according to the typology proposed by J. Møller and S.-E. Skaaning. External evaluation of Freedom Rating decreased to 1.5 in 2017-2018 and even 2.0 in 2019. The Democracy Score has also deteriorated as well, with Poland being awarded a score of 2.57 in 2017 and a score of 2.89 in 2019.

\section{Bibliography}

A. Ágh, Globalization and Central European Countries' Democratization. The Fourth Wave, [in:] R. Markowski, E. Wnuk-Lipiński (eds.), Transformative Paths in Central and Eastern Europe, Warsaw 2001.

A. Antoszewski, Wspótczesne teorie demokracji, Warszawa 2016.

M. Barański, S. Kubas, Samorząd terytorialny w Rzeczypospolitej Polskiej, [in:] M. Barański (ed.), Samorzad terytorialny w Europie Środkowej i Wschodniej, Toruń-Katowice 2009.

S. Berman, The Pipe Dream of Undemocratic Liberalism, «Journal of Democracy» 2017, vol. 28 , no. 3 .

W. Beywl, The Role of Evaluation in Democracy: Can it be Strengthened by Evaluation Standards? A European Perspective, «Journal of Multidisciplinary Evaluation» 2006, no. 6.

M. Bogaards, Case-based Research on Democratization, «Democratization» 2019, vol. 26, no. 1.

T. Bojarowicz, Partie i ugrupowania prawicowe w Polsce po 1989 roku, Torun 2013.

M. Burton, R. Gunther, J. Higley, Elites and Democratic Consolidation in Latin America and Southern Europe, [in:] R. Gunther, J. Higley (eds.), Elites and Democratic Consolidation in Latin America and Southern Europe: An Overview, Cambridge 1991.

A. Cooley, Countering Democratic Norms, «Journal of Democracy» 2015, vol. 26.

M. Coppedge, D. Kuehn, Introduction: absorbing the four methodological disruptions in democratization research?, «Democratization» 2019, vol. 26, no. 1.

R. Dahl, Demokracja i jej krytycy, Warszawa 2012.

L. Diamond, Facing up to the Democratic Recession, [in: ] L. Diamond, M.F. Plattner (eds.), Democracy in Decline? Baltimore 2015.

R.S. Foa, Y. Mounk, The Democratic disconnect, «Journal of Democracy» 2016, vol. 27, no. 3.

R.S. Foa, Y. Mounk, The Signs of Deconsolidation, «Journal of Democracy» 2017, vol. 28, no. 1.

R. Glajcar, Demokratyczny reżim polityczny. Relacje między legislatywa i egzekutywa w III Rzeczypospolitej, Katowice 2015. 
R. Glajcar, S. Kubas, Democratization in Poland in the Light of Quantitative Analysis Based on Selected Indices of the Years 2006-2016, [in:] A. Turska-Kawa, M. Hacek, Democratization Processes in Poland and Slovenia. Comparative Study, Maribor 2016.

R. Glajcar, System partyjny III Rzeczypospolitej, [in:] M. Barański, A. Czzyż, R. Glajcar, S. Kubas, M. Migalski, R. Rajczyk, M. Tyrała, Wspótczesne partie i systemy partyjne państw Grupy Wyszehradzkiej w procesie demokratyzacji, Katowice 2018.

S. Huntington, The Third Wave of Democratization, University of Oklahoma Press 1991.

J. Iwanek, Standardization of Modern Democracy, «Studia Politicae Universitatis Silesiensis» 2015, vol. 13.

I. Krastev, The Strange Death of Liberal Consensus, «Journal of Democracy» 2007, vol. 18, no. 4.

S. Kubas, Proces demokratyzacji i jego determinanty. Analiza na przyktadzie Republiki Czeskiej $i$ Wegier (1990-2016), Katowice 2018.

S. Levitsky, L. Way, The Myth of Democratic Recession, [in:] L. Diamond, M.F. Plattner (eds.), Democracy in Decline? Baltimore 2015.

J.J. Linz, A. Stepan, Problems of Democratic Transition and Consolidation: Southern Europe, South America, and Post-Communist Europe, Baltimore-London 1996.

R. Miernik, Reformy Prawa i Sprawiedliwości - nowy kierunek rozwoju państwa czy skuteczna strategia wyborcza, «Studia Politicae Universitatis Silesiensis» 2018, vol. 20.

M. Mieżejewski, Polityczne konsekwencje nowelizacji ustaw medialnych $w$ Polsce $w$ latach 2015-2016, «Politeja» 2018, vol. 15, no. 55.

J. Møller, M. Seeberg, S.-E. Skaaning, Asymmetrical Constraints on Democratic Regime Types: A Comparative Study, https://pdfs.semanticscholar.org/178e/23a4483f909582c556886d def4670c1e691a.pdf (4.12.2019).

J. Møller, S.-E. Skaaning, Beyond the Radial Delusion: Conceptualizing and Measuring Democracy and Non-democracy, «International Political Science Review» 2010, vol. 31, no. 3.

J. Møller, S.-E. Skaaning, Democracy and Democratization in Comparative Perspective. Conceptions, Conjunctures, Causes, and Consequences, London-New York 2013.

J. Møller, S.-E. Skaaning, Regime Types and Democratic Sequencing, «Journal of Democracy» 2013, vol. 24, no. 1.

J. Møller, S.-E. Skaaning, The Third Wave: Inside the Numbers, «Journal of Democracy» 2013, vol. 24 , no. 4.

F. Neiburg, International Encyclopedia of the Social $\&$ Behavioral Sciences, https://www.sciencedirect.com/science/article/pii/B0080430767009207?via\%3Dihub\#! (24.06.2020).

G. O'Donnell, P.C. Schmitter, Tentative Conclusions about Uncertain Democracies, [in:] G. O’Donnell, P.C. Schmitter, L. Whitehead (eds.), Transition from Authoritarian Rule, Baltimore 1986.

M.F. Plattner, Illiberal Democracy and the Struggle on the Right, «Journal of Democracy» 2019, vol. 30, no. 1.

G. Pridham, The Dynamics of Democratization. A Comparative Approach, London and New York 2000.

A. Przeworski, Democracy and the Market. Political and Economic Reforms in Eastern Europe and Latin America, Cambridge 1991.

J. Rupnik, Explaining Eastern Europe: the Crisis of Liberalism, «Journal of Democracy» 2018, vol. 29 , no. 3 .

J. Rupnik, From Democracy Fatigue to Populist Backslide, «Journal of Democracy» 2007, vol. 18 , no. 4.

G. Sartori, Teoria demokracji, Warszawa 1998. 
P.C. Schmitter, Crisis and Transition, but not Decline, [in:] L. Diamond, M.F. Plattner (eds.), Democracy in Decline? Baltimore 2015.

W. Skrzydło, Ustrój polityczny RP w świetle Konstytucji z 1997 r., Warszawa 2014.

M. Szuleka, M. Wolny, M. Szwed, Kryzys konstytucyjny w Polsce. 2015-2016, http://www.hfhr. $\mathrm{pl} / \mathrm{wp}$-content/uploads/2016/09/HFPC-Kryzys-konstytucyjny-w-Polsce-2015-2016.pdf (22.06.2020).

J.S. Valenzuela, Democratic Consolidation in Post-Transitional Setting: Notion, Process, and Facilitating Conditions. Kellogg Institute Working Paper, https://kellogg.nd.edu/publications/ workingpapers/WPS/150.pdf (25.03.2019).

L. Whitehead, Democratization. Theory and Experience, Oxford 2002.

W. Wojtasik, Funkcje wyborów w III Rzeczypospolitej. Teoria i praktyka, Katowice 2012.

W. Wojtasik, Lewica i prawica w Polsce. Aspekty ekonomiczno-społeczne, Sosnowiec 2011.

F. Zakaria, The Rise of Illiberal Democracy, «Foreign Affairs» 1997, vol. 76, no. 6. 